way, and that this was easily enough to rupture the tubing.

But the check valves were never designed to prevent such vapour leakage. They were required to do so only because of a lastminute change in the flight plan which delayed pressurization of the fuel tanks until the probe reached Mars.

Peter Wilhelm, director of the Naval Center for Space Technology and a panel member, says the late change to the flight plan was intended to avoid another possible leakage problem with a regulator valve. "If you were going to do it again, you'd do it in a way that you did not have to contend with either," he says. "It is an overall system design problem. We found a whole bunch of problems as a result of a lack of systems engineering."

The panel also criticizes the mission planners for switching off communications with Mars Observer during the fateful manoeuvre, pointing out that this decision was related to budget constraints. The telemetry would have remained active only if NASA had been able to afford to test the ability of a key transmitter component to withstand the shock of the manoeuvre. But the complete loss of communications with the spacecraft means that the agency will probably never know what actually happened to it and caused the mission's failure.

A second report, prepared by a team at the Jet Propulsion Laboratory (JPL) in Pasadena, California - which was responsible for managing the contractor on NASA's behalf - is even more scathing about the systematic deficiencies of the mission.

The JPL report notes "a lack of topdown, system-engineering design approach to fault protection" and adds that the investigation team's own brief survey uncovered numerous design problems which had not been noted during mission development. It also says that proper reliability assurance was not done, and that documentation was often wrong.

One former senior NASA official says privately, however, that JPL gave only low priority to the Mars Observer mission, which he describes as "an experiment by NASA to get JPL to produce a cheaper mission". The mission, the former official says, "skidded over the launch line with desperate budget difficulties".

The Mars Observer experience is certain to have an impact on NASA's programme management strategy in future. "We will be examining these findings and developing a corrective action plan," says Wesley Huntress, the agency's assistant administrator.

In particular, questions will undoubtedly be raised about the administration's strategy of increasing the amount of freedom given to government contractors, with more fixed-price contracts and less close monitoring on a day-to-day basis. With Mars Observer, NASA appears to have taken this "hands-off" strategy a step too far.

Colin Macilwain

\title{
Polish science gets priority - but little extra funding
}

Munich. Poland's new government has proposed a small increase in this year's budget for science, which has suffered severe cuts since the collapse of communism. The increase falls well short of a promise made by in November by Waldemar Pawlak, the prime minister, to double the country's research budget in 1994; but it does reflect the government's decision to make science one of its priorities.

The Polish Scientific Research Committee $(\mathrm{KBN})$, which functions as a research ministry, is hoping to persuade the government to give it more money later in the year. It is also encouraging research institutes to raise the notoriously low salaries of young researchers, many of whom have been leaving

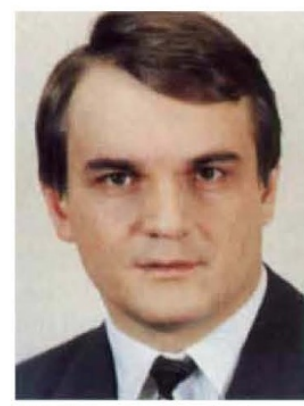

Waldemar Pawlak: optimistic promises.

basic research for better paid careers.

In his inaugural address to the national Parliament, the Sejm, last November, Pawlak promised to increase support for science, and in particular to follow guidelines adopted by the previous government in July, proposing to increase the research budget from 9,000 billion zloty (US\$450 million) to around 20,000 billion zloty in 1994 , subject to general budgetary constraints.

Such an increase would have raised the proportion of Poland's spending on research from 0.6 per cent to 1 per cent of its gross domestic product (GDP). But many doubted that such an increase was likely to materialize, given the depth of the country's economic problems.

In fact, next year's science budget will be virtually constant in real terms. The final budget proposals, which will be debated in Parliament within the next few weeks, offer science 11,460 billion zloty, only slightly higher than the predicted rate of inflation.

\section{Jury still out in case of Mongolian 'fossils'}

Beijing. The case of the "false" Chinese fossils reported recently by the Chinese Academy of Sciences may not be closed after all. Last year, a committee of palaeontologists concluded that shell-like fragments discovered in Mongolia by scientists from the Shenyang Institute of Geology and Mineral Resources, and reported as coming from the pre-Cambrian era, were not fossils after all, but organic fragments formed during laboratory analysis (see Nature, 366, 499; 1993).
Nevertheless science was one of five sectors given a rise in real terms.

Witold Karczewski, the president of KBN and a neurophysiologist who has already experienced four different governments since the committee was set up in 1991, had been hoping for 16 billion zloty, raising the level of funding to 0.8 per cent of GDP.

But he still hopes that science will benefit from a budget adjustment promised for summer, and is asking for a 'top-up' of 4,000 billion zloty. The extra money will be used to support priority research areas identified by the committee, including new technologies such as biotechnology and materials science, heart disease and cancer.

Meanwhile Karczewski is planning to distribute much more of the science budget directly to research institutes, and to reduce the amount given to other ministries to provide additional support for research in their own institutes. He hopes this will put pressure on these ministries to support his request for more funds.

This redistribution will have a further benefit. Poland's research institutes now enjoy considerable autonomy, and are able to set their own salaries for researchers. Although salaries differ between institutes, they are invariably low. Young scientists are paid particularly badly, receiving between a third and a half of what they might expect in industry.

Karczewski, worried by an internal braindrain of young scientists who are now staying in Poland but moving away from basic research, introduced a grant system three months ago under which young scientists can apply for an additional grant of up to 70 per cent of their institutional salary while working on their PhDs.

But he would prefer to see a general rise in salaries rather than relying on such $a d h o c$ arrangements. His decision to give research institutes more control of their budgets is intended to encourage them to respond to pressure from employees to raise salaries.

Alison Abbott

However, Su Yang-Zheng, head of the stratigraphy and palaeontology research section at the Shenyang institute, has now written to the academy saying that it is too early to decide whether the fossils in question are false. According to Yang-Zheng, whether the fossils are in fact merely chemical deposits "still remains a question that requires a great deal of scientific experiment". Since experts currently have differing opinions, he says, "no definitive conclusion can be made at present." You Qin Li 